\title{
Corrigendum: Photothermally triggered actuation of hybrid materials as a new platform for in vitro cell manipulation
}

\author{
Amy Sutton, Tanya Shirman, Jaakko V.I. Timonen, Grant T. England, Philseok Kim, Mathias Kolle, \\ Thomas Ferrante, Lauren D. Zarzar, Elizabeth Strong \& Joanna Aizenberg
}

Nature Communications 8:14700 doi: 10.1038/ncomms14700 (2017); Published 13 Mar 2017; Updated 14 Aug 2017

The financial support for this Article was not properly acknowledged. The acknowledgements should include a reference to support, 'by the ONR under award number N00014-16-1-3169 (Designing a Dynamic Platform that Provides Multiple Defense Mechanisms against Fouling)' instead of 'ONR under award number N00014-15-1-2157 (cell manipulation)'.

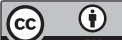

This work is licensed under a Creative Commons Attribution 4.0 International License. The images or other third party material in this article are included in the article's Creative Commons license, unless indicated otherwise in the credit line; if the material is not included under the Creative Commons license, users will need to obtain permission from the license holder to reproduce the material. To view a copy of this license, visit http://creativecommons.org/licenses/by/4.0/

(C) The Author(s) 2017 